\title{
MANFAAT PENERAPAN BUDAYA KESELAMATAN
}

\section{PASIEN DI RUMAH SAKIT}

\author{
Friderikus Zebua \\ zebuafriderikus@gmail.com
}

\section{LATAR BELAKANG}

Keselamatan pasien merupakan suatu sistem yang harus diterapkan di rumah sakit untuk mencegah terjadinya situasi yang berpontensi mengakibatkan cedera yang seharusnya tidak terjadi atau biasa disebut insiden keselamatan pasien mutu Pelayanan RS merupakan kualitas RS dalam melaksanakan pelayananannya. Mutu pelayanan yang baik akan berdampak pada kepuasan pasien dan perawat sebagai pelaksana.

Kesehatan dan Keselamatan Kerja (K3) merupakan suatu upaya perlindungan kepada tenaga kerja dan orang laain yang memasuki tempat kerja terhadap bahaya dari akibat kecelakaan kerja. Tujuan K3 adalah mencegah, mengurangi resiko penyakit dan kecelakaan akibat kerja (KAK) serta meningkatkan derajat kesehatan para pekerja sehingga produktivitas kerja meningkat derajat kesehatan para pekerja sehingga produktivitas kerja meningkat. Pelayanan kesehatan dirumah sakit merupakan pemenuhan kebutuhan dan tuntutan dari pemakan jasa pelaayanan atau pasien yang mengharapkan penyembuhan dan pemulihan yang berkualitas dan penyediaan pelayanan kesehatan yangnyaman dan aman.

Penyelenggaraan pelayanan kesehatan rumah sakit di indonesia menghadapi tantangan yang semakinn komplek dalam lingkungan pasar yang kompetitif, rumah sakit harus aktif mencari apa yang diingankan pelanggan dan berusaha memenuhi nya agar bisa bertahan dan cara mengetahui keinginan pasien adalah dengan meminta pendapat tentang pelayanan yang telah diterima

Kepuasan pasien terhadap pelayanan rumah sakit dapat terlihat dari jumlah kunjungan pasien yang semakin meningkat atau dari peningkatan angka Bed Ocupation Rate (BOR). Sementara kepuasan perawat dapat dilihat dari keberhasilan perawat dalam merawat pasien. PenelitianNugroho (2012) pun menunjukkan bahwa kepuasan kerja berpengaruh positif terhadap komitmen organisasi. Banyak manfaat yang dapat diperoleh dari penerapan Keselamatan Pasien 
Rumah Sakit (KPRS), salah satunya adalah kepuasan pasien meningkat (Maryam, 2009). Diperjelas oleh Lumenta (Komite Keselamatan Rumah Sakit, 2008) yang menyatakan bahwa keuntungan dari penerapan KPRS di rumah sakit adalah komunikasi dengan pasien berkembang, risiko klinis menurun, keluhan pasien berkurang serta mutu pelayanan dan citra RS meningkat

\section{METODE}

Metode yang digunakan dalan penelitian manfaat keselamatan pasien dan kesehatan pasien dirumah sakit adalah metode litelture review yaitu menggunakan kemampuan dan pemahaman dalam manfaat keselamatan dan kesehatan pasien dirumah sakit sehingga mampu menjelaskan dan menerapkan tentang manfaat keselamatan dan kesehatan pasien dirumah sakit sesuai dengan prosedur.

\section{HASIL}

Menurut Murrells, Robinson, dan Griffiths (2009) kepuasan kerja perawat telah diidentifikasi sebagai interaksi yang kompleks antara karyawan dengan lingkungan kerja, sedangkan menurut Layne, Singh, Getz, dan Hohenshil (2001) kepuasan kerja menggambarkan bagaimana perasaan seseorang tentang pekerjaannya Banyak faktor yang memengaruhi kepuasan kerja perawat. Faktor.spesifiknya ada tiga faktor yang mempengaruhi kepuasan kerja perawat yaitu: interpersonal relationship, patient care, dan organizing nursing work (Utriainen \& Kyngas, 2009). Sementara menurut Hayes et al (2010), kepuasan kerja perawat didasarkan atas tiga hal, yaitu intrapersonal, interpersonal, dan extrapersonal.Dapat saaya simpulkan bahwa menghasilkan suatu pembelajaran melalui pemahaman dari penelitian ini untuk melakukan penerapan keselamatan dan kesehatan pasien dirumah sakit melalui pemahaman manfaat keselamatan pasien.

\section{PEMBAHASAN}

Kepuasan merupakan perasaan seseorangbyang terpenuhi akan kebutuhan, harapan dan keinginan. Kepuasan pasien dapat diartikan suatu keinginan pasien untuk mendapatkan pelayanan keperawatan yang baik sehingga merasa puas. Pasien adalah orang sakit atau penderita yang memperoleh pelayanan di suatu unit pelayanan kesehatan (KBBI, 2017). 
Kepuasan pasien adalah perasaan senang ataupun perasaan kecewa seorang pasien setelah membandingkan hasil penampilan produk dan jasa dengan harapan yang diinginkan (Kotler \& Keller, K, 2012). Kepuasan pasien adalah opini pasien tentang perawatan yang diterima dari perawat (Wagner \& Bear, 2008). Kepuasan pasien merupakan emosi, persepsi dan perasaan tentang pelayanan yang diberikan (Mohan \& Kumar, 2011). Kepuasan pasien dapat diartikan sebagai keluaran (outcome) layanan kesehatan..Dengan demikian kepuasan pasien merupakan salah satu tujuan dari peningkatan mutu layanan kesehatan..Kepuasan pasien adalah suatu tingkat perasaan pasien yang timbul sebagai akibat dari kinerja layanan kesehatan yang diperolehnya setelah pasien membandingkannya dengan yang diharapkannya (Mezemir, Getachew, \& Gebresiassie, 2014). Kondisi harapan seseorang yang diterima tidak sesui maka individu tersebut akan kecewa.

Kepuasan pasien adalah keinginan pasien akan mendapatkan pelayanan keperawatan yang baik sehingga merasa puas yang dilihat dari dimensi: bukti nyata,kehandalan, ketanggapan, responsibiliti, jaminan dan empati (Lei \& Jolibert, 2012). Dimensi pelayanan kesehatan yang mempengaruhi kepuasan pasien terdiri Tangibles (bukti fisik/ bukti nyata) Tangibel adalah bukti fisik atau bukti nyata yang meliputi fasilitas fisik, perlengkapan, sarana komunikasi, kemutahiran peralatan yang digunakan, kondisi sarana, kondisi (sumber daya manusia), penampilan seluruh tenaga kesehatan termasuk perawat di suatu rumah sakit. Dimensi tangible adalah

Rumah sakit adalah sarana pelayanan kesehatan yang dibutuhkan ketika seseorang sakit dan membutuhkan bantuan dengan tujuan untuk menyelamatkan kondisi pasien. Dengan berlalunya waktu dan perkembangan ilmu pengetahuan dan teknologi rumah sakit tidak hanya menjadi tempat untuk menyelamatkan.pasien. Berbagai layanan dapat diakses oleh pasien yang membutuhkan bantuan. Pasien yang memerlukan bantuan menyeluruh dan intensif selama.24 jam dapat mengakses layanan rawat inap. Perawatan rawat inap memiliki peran penting dalam pelayanan perawatan untuk observasi, diagnosis, pengobatan atau upaya perawatan kesehatan lainnya. Keselamatan pasien di rumah sakit melibatkan partisipasi dari semua petugas kesehatan, terutama perawat.

Program keselamatan pasien ini memberikan berbagai manfaat bagi rumah sakit antara lain: 
1. Adanya kecenderungan "Green Product" produk yang aman di bidang industri lain seperti halnya menjadi persyaratan dalam berbagai proses transaksi, sehinggasuatu produk menjadi semakin laris dan dicari masyarakat.

2. Rumah sakit yang menerapkan keselamatan pasien akan lebih mendominasi pasar jasa bagi perusahaan-perusahaan danAsuransi-asuransi dan menggunakan Rumahsakit tersebut se3bagai provider kesehatan karyawan/klien mereka, dan kemudian diikuti oleh masyarakat untuk mencari Rumah sakit yang aman

3. Kegiatan Rumah sakit akan lebih memfokuskan diri dalam kawasan keselamatan pasien.

Keselamatan pasien rumah sakit adalah suatu sistem yang diterapkan untuk mencegah terjadinya cedera akibat perawatan medis dan kesalahan pengobatan melalui suatu sistem assesment resiko, identifikasi dan pengelolaan faktor risiko, pelaporan dan analisis insiden, kemampuan belajar dan tindak lanjut dan insident serta impelementasi solusi untuk meminimalkan timbulnya risiko (Dep Kes RI 2006) . keselamatan pasien merupakan suatu sistem untuk mencegah terjadinya cedera yang disebabkan oleh kesalahan akibat melaksanakan suatu tindakan atau tidak mengambil tindakan yang seharusnya diambil.

Dimensi pelayanan kesehatan yang mempengaruhi kepuasan pasien terdiri :

1. Tangibles (bukti fisik/ bukti nyata) Tangibel adalah bukti fisik atau bukti nyata yang meliputi fasilitas fisik, perlengkapan, sarana komunikasi, kemutahiran peralatan yang digunakan, kondisi sarana, kondisi (sumber daya manusia), penampilan seluruh tenaga kesehatan termasuk perawat di suatu rumah sakit. Dimensi tangible adalpemberian arahan untuk memudahkan menemukan rumah sakit, daya tarik kebersihan lingkungan, kerapihak kecerdasan staf dan ketersediaan peralatan rumah sakit (Peprah, 2014). Pasien merasa puas dengan fasilitas rumah sakit yang menyediakan batastempat tidur sehingga privasi pasien terjaga dengan baik dan mengurangi risiko jatuh

2. Reliability (kehandalan) Kehandalan adalah kemampuan seseorang untuk menyediakan pelayanan yang layak atau tidak bagi pasien di rumah sakit. Kehandalan yaitu kemampuan rumah sakit dalam memberikan pelayanan secara efisien, tingkat pelayanan yang sama dan 
pasien memiliki waktu yang cukup untuk memberitahu masalah kesehatannya (Peprah, 2014). Kehandalan merupakan pemberian perawatan secara professional sejak pasien masuk sampai keluar rumah sakit dan pelayanan yang kompeten,lancar tanpa komplikasi atau masalah baru dan terhindar dari kesalahan prosedur tindakan. Kehandalan diartikan sebagai kemampuan perawat dalam memberikan pelayanan keperawatan secara kompeten, efisien, tidak terjadi masalah baru akibat pemberian asuhan keperawatan, serta memiliki waktu yangcukup untuk untuk pasien.

3. Responsiveness (ketanggapan) Ketanggapan didefinisikan sebagai kesigapan atau kecepatan respon dari perawat dalam menanggapi keluhan pasien di rumah sakit. Sebesar $50 \%$ pasien membutuhkan perhatian dari perawat untuk meningkatkan rasa nyaman terhadap sakit yang dirasakannya. Ketanggapan petugas rumah sakit menanggapai kasus-kasus darurat, bereaksi segera untuk memenuhi kebutuhan pasien dalam keadaan darurat (Peprah, 2014). 18 Universitas Indonesia .

4. Assurance (jaminan) Jaminan yaitu tanggungan akan kewajiban seseorang tentang keselamatan, barang dan harta benda. Pasien membutuhkan jaminan terhadap kualitas pelayanan asuhan keperawatan yang diberikan oleh perawat ketika berinteraksi. Jaminan bagi pasien adalah tanggungan akan kewajiban perawat tentang keselamatan dan jaminan kualitas pelayanan asuhan keperawatan yang diberikan oleh perawat dalam pemberian pelayanan dengan baik. Interaksi yang baik dalam pemberian pelayanan menciptakan reputasi rumah sakit yang baik sehingga mampu menjamin kualitas pelayanan yang diberikan (Peprah, 2014). Harapan pasien sebelum masuk rumah sakit untuk diperlakukan dengan peduli dan bermartabat $78 \%$ dan pasien mengharapkan perawat memiliki sikap sopan ketika berinteraksi dengan pasien 18\% (Dzomeku et al., 2013).

5. Empathy (kepedulian) Kepedulian merupakan sikap seseorang ikutbmerasakan suasana hati orang lain. Kepuasan pasien terhadap asuhan keperawatan di rumah sakit disebabkan sikap peduli oleh perawat, senyum dan menghormati pasien (Tang, Soong, \& Lim, 2013). Empati perawat merupakan sikap kepedulian perawat, ikut merasakan suasana hati pasien dalam memberikan asuhan keperawatan di rumah sakit. Faktor lain yang mempengaruhi kepuasan pasien yaitu perawatan individu yang diberikan, pemahaman petugas akan kebutuhan spesifik pasien dan layanan yang akan diberikan kepada pasien diberitahu terlebih dahulu 
(Peprah, 2014).

\section{PENUTUP}

Keselamatan Pasien adalah suatu sistem dimana rumah sakit membuat asuhan pasien lebih aman, mencegah terjadinya cidera yang disebabkan oleh kesalahan akibat melaksanakan suatu tindakan atau tidak mengambil tindakan yang seharusnyadiambil. Pada prinsipnya keselamatan pasien bukan berarti harus tidak ada risiko sama sekali agar semua tindakanmedis dapat dilakukan. Rumah sakit sebagai sarana pelayanan kesehatan pada dasarnya adalah untuk menyelamatkan pasien, Perawat harus memberikan pelayanan yang baik kepada pasien di rumah sakit agar pasien bisa merasakan manfaat pelayanannya.

\section{DAFTAR PUSTAKA}

Brown, D. S., \& Wolosin, R. (2013). Safety Culture Relationships with Hospital Nursing Sensitive Metrics. Journal for Healthcare Quality, 61-74.

Brown, J. K. (2016). Relationship between Patient Safety Culture and Safety Outcome Measures among Nurses. ProQuest Dissertations Publishing, 1-80.

Cahyadi, S. R., \& Mudayana, A. A. (2014). Hubungan mutu pelayanan dengan kepuasan pasien di RS PKU Muhammadiyah Yogyakarta unit II. Journal Respati, 40-49

Depkes RI. (2008). Panduan Nasional Keselamatan Pasien Rumah Sakit (Patient Safety): Utamakan Keselamatan Pasien. Jakarta: Depkes RI.

Lombogia, A., Rottie, J., \& Karundeng, M. (2016). Hubungan Perilaku dengan Kemampuan Perawatan dalam Melaksanakan Keselamatan Pasien (Patient Safety) di Ruang Akut Instalasi Gawat Darurat RSUPProf.DR.R.D. Kandou Manado. Jurnal Ners Dan Kebidanan Indonesia, 4. 
Nugroho, M. K. (2012). Pengaruh stres peran dan kepuasan kerja terhadap komitmen organisasi perawat di RSPI Sulianti Saroso (Skripsi tidak dipublikasikan). Universitas Indonesia, Jakarta.

Panesar, S. S., Stevens, A. C.-S., Salvilla, S. A., \& Sheikh, A. (2017). At a Glance keselamatan pasien dan peningkatan mutu pelayanan kesehatan. (Sutoto \& NefroNico A. Lumenta, Eds.) (20th ed.). Jakarta: Erlangga.

Permadhi, A. (2013). Hubungan Budaya Keselamatan Pasien Dalam Pelayanan Keperawatan dan Insiden Keselamatan Pasien di Instalasi Rawat Inap RSD dr. Soebandi. Skripsi. Jember. Potter, P., Perry, A., Stockert, P., \& Hall, A. (2017). Fundamentals of Nursing (8th ed.). Southern Illinois: Elsevier Inc. Peraturan Menteri Kesehatan Indonesia (2011) 1691/Menkes/Per/VIII/2011

Putra, A. Setia. Firawati dan Pabuty, Aumas (2012). Pelaksana Program Keselamatan Paisen Di RSUD Solok. Jurnal Kesehatan Masyarakat. Vol 6, No. 2.

Simamora, R. H., \& Fathi, A. (2019). The Influence Of Training Handover Based SBAR Communication For Improving Patients Safety. Indian journal of public health research \& development, 10(9), 1280-1285. 